\title{
Global Assessment of Silver Pollution using Sperm Whales (Physeter macrocephalus) as an Indicator Species
}

\author{
Laura C Savery 1,2,3,4, Sandra S Wise ${ }^{1,2,3,4}$, Carolyne Falank ${ }^{1,2,3}$, James Wise ${ }^{1,2,4}$, Christy Gianios Jr,2,3,4, W Douglas Thompson ${ }^{2,3}$, Christopher \\ Perkins $^{5}$, Michael D Mason ${ }^{2,6}$, Roger Payne ${ }^{2,4}$, lain Kerr ${ }^{2,4}$ and John Pierce Wise Sr ${ }^{1,2,3,4 *}$
}

${ }^{1}$ Wise Laboratory of Environmental and Genetic Toxicology, University of Southern Maine, 96 Falmouth St., Portland, ME, 04104, USA

${ }^{2}$ Maine Center for Toxicology and Environmental Health, University of Southern Maine, 96 Falmouth St., Portland, ME, 04104, USA

${ }^{3}$ Department of Applied Medical Sciences, University of Southern Maine, 178 Science Building, Portland, ME, 04104, USA

${ }^{4}$ Ocean Alliance, 32 Horton Street, Gloucester, MA, 01930, USA

${ }^{5}$ Center for Environmental Sciences and Engineering, University of Connecticut, 3107 Horsebarn Hill Road, U-4210, Storrs, CT, 06269, USA

${ }^{6}$ Institute for Molecular Biophysics, Department of Chemical and Biological Engineering, University of Maine, Orono, ME, 04469, USA

\begin{abstract}
Silver pollution in the marine environment is of concern, particularly, with the rapid increasing use of silver nanoparticles in consumer products providing additional sources of silver emissions. Silver is highly toxic and known to bioaccumulate in aquatic organisms; however, the risk silver poses to the marine ecosystem is poorly understood. The sperm whale (Physeter macrocephalus), a toothed whale having a wide global distribution and high trophic level, is a sentinel of ocean health. The aim of this study was to provide a global baseline for silver as a marine pollutant using the sperm whale as an indicator species. Skin biopsies were collected in free-ranging sperm whales around the globe during the voyage of the research vessel, Odyssey, during 2000 and 2005. Total silver levels were measured in 298 sperm whales from 16 regions. Detectable levels were found in 176 whales and ranged from 0.1 to $4,179.0 \mu \mathrm{g} / \mathrm{g} \mathrm{ww}$ with a global mean level of $16.9 \pm 14.1 \mu \mathrm{g} / \mathrm{g} \mathrm{ww}$. The highest mean level was found in whales sampled in waters near Seychelles with $123.3 \mu \mathrm{g} / \mathrm{g} \mathrm{ww}$, and the lowest mean in whales near Chagos with $0.1 \mu \mathrm{g} / \mathrm{g} \mathrm{ww}$. These data provide an important global baseline for silver pollution that precedes the recent emergence of silver nanoparticles.
\end{abstract}

Keywords: Silver; Sperm whale; Skin biopsies; Atlantic Ocean; Indian Ocean; Pacific Ocean; Mediterranean Sea

Abbreviations: Ag: Silver; AgNPs: Silver Nanoparticles; ww: wet weight; dw: dry weight

\section{Introduction}

Silver $(\mathrm{Ag})$ is a pollutant of concern in marine waters due to its toxicity, chemistry and bioavailability [1]. $\mathrm{Ag}$ is one of the most toxic trace metals known [2] secondary to only mercury [3]. Ag contamination has been a marine concern for some time, largely due to its toxicity in marine invertebrates and fish $[1,4]$.

$\mathrm{Ag}$ can enter the marine environment from mining, photographic industry, combustion of wastes (fossil fuels, municipal and industrial), electronic applications and cloud seeding $[3,5,6]$. Natural sources include weathering of rock and soil erosion [5]. The natural concentration of $\mathrm{Ag}$ in marine waters is very low, 0.1 to $0.3 \mathrm{ng} / \mathrm{l}$, and in oxidized sediments is also low, $0.1 \mu \mathrm{g} / \mathrm{g}$ dry weight (dw), making any amount of anthropogenic input a substantial enrichment of this metal into the environment [1]. Currently, $\mathrm{Ag}$ is regulated at $1.9 \mu \mathrm{g} / \mathrm{L}$ in saltwater [7].

Once in seawater, Ag binds with chloride keeping a substantial portion in solution allowing for enhanced bioavailability to marine life and increased distribution by currents $[2,8]$. At lower salinity, Ag exists as $\mathrm{AgCl}$ and is bioavailable, and at higher salinity $\mathrm{Ag}$ exists as $\mathrm{AgCl}, \mathrm{AgCl}^{2-}$ and $\mathrm{AgCl}^{3-}$ and is less bioavailable [9]. Ag concentration in seawater increases with depth so that surface waters contain $<1-25$ $\mathrm{pM}$ and deep waters contain 7-80 pM depending on region $[9,10]$. Additionally, Ag distributions appear to be dependent on silicate concentration in vertical profiles of the water column with a positive correlation of Ag to silicate with increasing depth [11].

Recently, Ag has become commonly used as a nanoparticle material in a wide range of consumer products including washing machines, detergents, clothing, food packaging, containers, dietary supplements, medical devices, plastics and refrigerators due to its antibacterial properties [12-15]. The antimicrobial properties of silver nanoparticles (AgNPs) are of particular concern for if, inadvertently, they enter the marine ecosystem they may inhibit the natural microbial activity important for decomposition, nutrient cycling and removal [15]. AgNPs have the potential to be more toxic than dissolved-Ag [16]; however, there is debate as to whether the toxicity is due to the nanoparticle or the dissolved Ag released from the nanoparticle in the presence of water [14]. AgNPs have not had clear guidelines for the regulation of their release into the environment established [17].

The extent of Ag pollution prior to the dawn of the nanoparticle age is poorly understood. Measurements of $\mathrm{Ag}$ in marine waters are not widespread and assessments of $\mathrm{Ag}$ levels in indicator marine species have only been done sporadically. Studies in cetaceans show that $\mathrm{Ag}$ bioaccumulates [18-21], but so far a baseline for Ag has not been determined. Such a baseline would be useful in future assessments of the potential effects of AgNPs on Ag levels in the marine environment. Additionally, most studies on Ag compounds investigate acute time points. However, chronic low levels of Ag may lead to toxic body

*Corresponding author: Dr. John Pierce Wise, Sr., Wise Laboratory, Maine Center for Toxicology and Environmental Health, University of Southern Maine, P.O. Box 9300, 96 Falmouth Street, Portland, Maine, 04104, USA, Tel: +1-207228-8050; Fax: +1-207-228-8518; E-mail: John.Wise@usm.maine.edu

Received December 05, 2012; Accepted February 28, 2013; Published March 04,2013

Citation: Savery LC, Wise SS, Falank C, Wise J, Gianios C Jr (2013) Global Assessment of Silver Pollution using Sperm Whales (Physeter macrocephalus) as an Indicator Species. J Environ Anal Toxicol 3: 169. doi:10.4172/2161 0525.1000169

Copyright: (c) 2013 Savery LC, et al. This is an open-access article distributed under the terms of the Creative Commons Attribution License, which permits unrestricted use, distribution, and reproduction in any medium, provided the original author and source are credited. 
Citation: Savery LC, Wise SS, Falank C, Wise J, Gianios C Jr (2013) Global Assessment of Silver Pollution using Sperm Whales (Physeter macrocephalus) as an Indicator Species. J Environ Anal Toxicol 3: 169. doi:10.4172/2161-0525.1000169

burden in long-lived organisms, such as the sperm whale, and need to be investigated further especially with the rise of silver nanotechnology.

Between 2000 and 2005, the research vessel, Odyssey, collected skin biopsies from free-ranging sperm whales from the Pacific, Indian and Atlantic Oceans and the Mediterranean Sea. Sperm whales have a global distribution and feed high on oceanic food chains and may be at risk for accumulation of Ag in their tissues. Since these samples were collected prior to the extensive use of AgNPs in consumer products, these biopsies provide a rare opportunity to establish a global baseline prior to the introduction of this new class of chemicals.

\section{Materials and Methods}

We measured total Ag concentrations in 298 free-ranging sperm whale skin samples collected from 16 regions around the globe (Figure 1) with 94 samples in the Pacific, 156 in the Indian, 23 in the Mediterranean and 25 in the Atlantic. We considered 194 female and 104 male sperm whales including 51 adult and 53 subadult males.

\section{Biopsies}

During the voyage of the research vessel, Odyssey, between 2000 and 2005, skin biopsies were collected from free-ranging sperm whales as described previously [22]. Sampling was carried out simultaneously with photo-identifications of individual whales to minimize duplication. The behavior of all whales sampled appeared to be healthy. Samples were taken from the whale's flank, a location that has been shown to elicit the fewest reactions [23]. We used a $50 \mathrm{~mm}$ stainless steel cylindrical biopsy dart. Samples were removed from the biopsy dart and divided into two pieces at the interface between skin and blubber. These two pieces were stored separately for later genetic and metal analysis. All tissue samples were frozen at $-20^{\circ} \mathrm{C}$ within a few minutes of collection. The samples were shipped frozen to the Wise Laboratory. Age classification of males as subadult or adult was estimated by the length of the whale; however, classification of females could not be made reliably because of their overall smaller size compared to males. Sloughed skin samples were additionally collected with a net and were also classified for gender and analyzed for Ag concentrations.

\section{Genotyping}

Gender was determined by genotyping as published in our methods [23]. DNA was extracted from a piece of whale skin, and gender was determined by PCR amplification reactions in which the SRY (male determining factor) gene was amplified. The keratin gene was used as an amplification control for all samples. Male samples showed both the keratin band ( 311bp) and SRY (male) band at $\sim 152 \mathrm{bp}$. Female samples showed only the keratin band at $\sim 311 \mathrm{bp}$. Primer sequences were the following:

\section{SryPMF: 5'CATTGTGTGTGGTCTCGTGATC}

SryPMR: 5'AGTCTCTGTGCCTCCTCGAA

KF: 5'AGATCAGGGGTTCATGTTTCTTTGC

KR: 5'TTTACAGAGGTACCCAAGCCTAAG

\section{Inductively coupled plasma mass spectroscopy}

Whale skin samples were analyzed for total Ag using a Perkin-

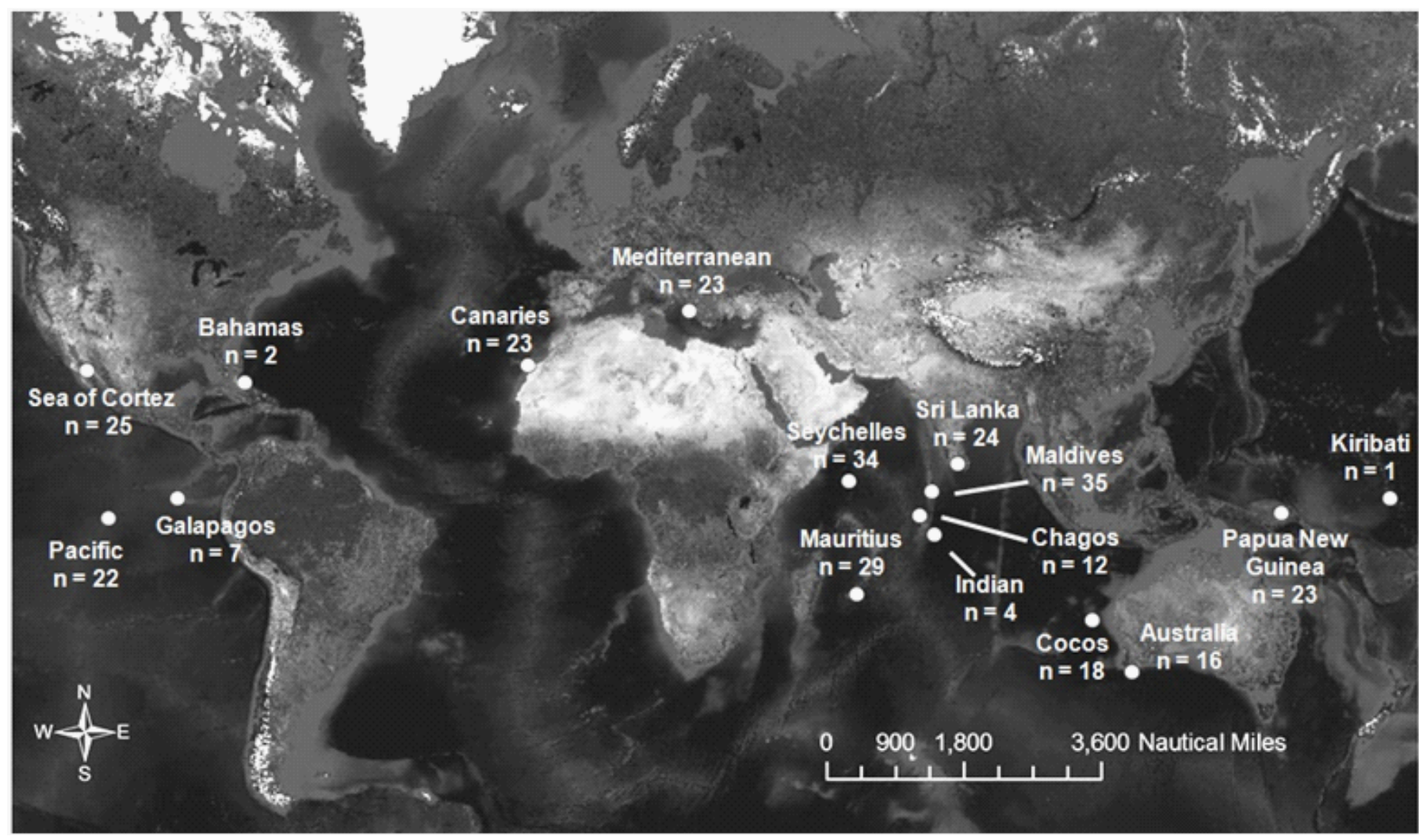

Figure 1: Regional distribution of sperm whale samples during the Voyage of the Odyssey. Samples are organized into 16 regions with sample size ( $\mathrm{n}$ ) denoted. The voyage began in the Sea of Cortez traveling westward ultimately ending in Massachusetts, USA. 
Citation: Savery LC, Wise SS, Falank C, Wise J, Gianios C Jr (2013) Global Assessment of Silver Pollution using Sperm Whales (Physeter macrocephalus) as an Indicator Species. J Environ Anal Toxicol 3: 169. doi:10.4172/2161-0525.1000169

Elmer/Sciex ELAN inductively coupled plasma-mass spectrometer (ICP-MS) according to our published methods [23]. Samples were rinsed with deionized water and allowed to air dry in a laminar flow hood to minimize contamination. Approximately $0.1 \mathrm{~g}$ of tissue was placed in a digestion vessel, $2 \mathrm{ml}$ of Optima grade nitric acid (Fisher Scientific, Pittsburg, PA) was added, the vessel placed in a hot block, and refluxed at $95^{\circ} \mathrm{C}$ for $4 \mathrm{~h}$. The sample was cooled, $2 \mathrm{ml}$ Optima grade hydrogen peroxide (Fisher Scientific, Pittsburg, PA) and deionized water $(3: 2 \mathrm{v} / \mathrm{v})$ was added, heated until the effervescence subsided, cooled, and brought up to a final volume of $20 \mathrm{ml}$. Standard quality assurance procedures were employed (Table 1) and include the analysis of standard reference materials, a duplicate sample and a pre-digestion spike. Instrument response was evaluated initially and after the 10 samples, using commercially available calibration verification standards (Claritas PPT multi-element solution 2- Spex CertiPrep, Metuchen, NJ individual elemental standards - SCP Science, Baie-D’Urfe, Quebec, Canada) and a blank. All calibration verifications $(n=5)$ were within the acceptance criterion of $85-115 \%$ recovery and all the preparation blank values were below $3 \times$ the limit of detection. Standard reference material (DOLT-4 - NIST, Charleston, SC) was used to assess method performance, where applicable. Interference check solutions (ICS A and ICS A+B- High Purity Standards, Charleston, SC) were analyzed with all sample runs checking for matrix effects that might interfere with sample analysis. The mean limit of detection (LOD) and project quantitation limit (PQL) values are presented in Table 1, and the PQL is 10 times higher than the LOD due to slight variability between samples due to differences in sample mass. The LOD was the lowest analyte concentration likely to be reliably distinguished from the blank and at which detection is feasible. The LOD was previously determined by utilizing both the measured blank and test replicates of a matrix matched sample known to contain a low concentration of analyte. Additionally, a series of PQL samples was run for each element to assess low concentration analytical performance, with an acceptance criterion of $50-150 \%$. All samples were diluted $2 \times$ for analysis by ICP-MS.

Results are reported in units of $\mu \mathrm{g} / \mathrm{g}$ wet weight of tissue $(\mu \mathrm{g} / \mathrm{g}$ $\mathrm{ww})$. Levels in the literature are mostly reported as per dry weight (dw) of tissue and do not include information on water content. Hence in order to compare our data with literature, we transformed literature values to wet weight values by multiplying them by a factor of 0.25 , which corresponds to the dry/wet weight ratio of skin and blubber.

\section{Mapping}

Whale locations were plotted using ArcGIS 9: ArcMap Version 9.3.1. These maps allowed us to infer geographical areas in which exposure may have occurred.

\section{Statistics}

Mean values were compared using analysis of variance. Differences for individual pairs of means were assessed via t-tests with the Bonferroni correction for multiple comparisons also according to our published methods [23]. When Ag was not detected in a specimen, a value of one-half the detection limit was used in the analysis. Statistical testing was performed on log-transformed data due to the skew of the distributions of the untransformed data. The statistical analyses were all conducted in SAS 9.2 (SAS Institute, 2004).

\section{Results}

\section{Silver levels by region}

Ag was detected in 178 of the 298 sperm whales sampled with a global mean of $16.9 \pm 14.1 \mu \mathrm{g} / \mathrm{g}$ ww and detectable levels ranging from 0.04 to $4,179 \mu \mathrm{g} / \mathrm{g}$ ww (Table 2). There are two samples in the dataset with high Ag concentrations that should be noted, a subadult male in Seychelles with a Ag concentration of $4,179 \mu \mathrm{g} / \mathrm{g}$ ww and a female in Sri Lanka with $297.3 \mu \mathrm{g} / \mathrm{g}$ ww. Mean Ag concentrations for the four general regions of the world, Pacific, Indian, Mediterranean and Atlantic, were 4.2, 23.1, 1.5 and $5.9 \mu \mathrm{g} / \mathrm{g} w \mathrm{w}$, respectively. By region, the highest mean $\mathrm{Ag}$ concentration was measured in waters near Seychelles $(\mathrm{n}=34)$ with $123.3 \pm 122.9 \mu \mathrm{g} / \mathrm{g}$ ww ranging from 0.1 to $4,179 \mu \mathrm{g} / \mathrm{g}$ ww and Sri Lanka $(\mathrm{n}=24)$ with $12.5 \pm 12.4 \mu \mathrm{g} / \mathrm{g}$ ww ranging from 0.1 to $297.3 \mu \mathrm{g} / \mathrm{g} w \mathrm{w}$. The lowest regional Ag mean concentration was in whales sampled during the Indian Ocean crossing with all four samples undetectable (onehalf $\mathrm{LOD}=0.04 \mu \mathrm{g} / \mathrm{g} \mathrm{ww}$ ) and in whales near the Chagos Archipelago in the Indian Ocean with $0.1 \pm 0.1 \mu \mathrm{g} / \mathrm{g}$ ww ranging from 0.1 to 0.7 $\mu \mathrm{g} / \mathrm{g}$ ww. The variation among regions was statistically significant $(\mathrm{F}(15,281)=5.40 ; \mathrm{p}<0.0001)$. Pair-wise $\mathrm{t}$-tests showed regions that differed $(\mathrm{p}<0.05)$ included: Mauritius to Papua New Guinea; Sri Lanka to Papua New Guinea and Sea of Cortez; and Papua New Guinea to Chagos, Cocos, Indian Ocean, Maldives, Mauritius, Seychelles and Sri Lanka.

\section{Silver levels by gender}

We considered Ag levels by gender (Table 3). Detectable Ag levels were found in 107 of the 194 females sampled with a global mean of $3.5 \pm 1.7 \mu \mathrm{g} / \mathrm{g}$ ww ranging from 0.04 to $297.3 \mu \mathrm{g} / \mathrm{g}$ ww. Detectable $\mathrm{Ag}$ levels were found in 71 of the 104 males sampled with a global mean of $42.0 \pm 40.2 \mu \mathrm{g} / \mathrm{g} w \mathrm{w}$ ranging from 0.1 to $4,179 \mu \mathrm{g} / \mathrm{g}$ ww. The global mean Ag concentration was not statistically different in males compared to females $(\mathrm{F}(1,295)=3.40 ; \mathrm{p}=0.07)$ even when females were compared to adult males $(\mathrm{F}(1,242)=2.35 ; \mathrm{p}=0.13)$ and to subadult males $(\mathrm{F}(1,244)=1.87 ; \mathrm{p}=0.17)$. With removal of the male from Seychelles with a Ag concentration of $4,179 \mu \mathrm{g} / \mathrm{g}$ ww, the global mean for males was 1.9 $\pm 0.8 \mu \mathrm{g} / \mathrm{g}$ ww ranging from 0.1 to $75.6 \mu \mathrm{g} / \mathrm{g} w \mathrm{w}$, the global mean $\mathrm{Ag}$ concentration still was not statistically different when comparing males to females $(\mathrm{F}(1,294)=2.25 ; \mathrm{p}=0.13)$.

Whales were not evenly distributed by region as females were not found to biopsy in the Galapagos, Indian Ocean crossing or Chagos. Similarly, males were not found to biopsy in the waters around Kiribati and Cocos Islands. All other regions had a mix of males and females at the time the Odyssey was present and collecting samples. Controlling

Table 1: Quality assurance and quality control data for Ag analysis

\begin{tabular}{|c|c|c|c|c|c|c|c|}
\hline Metal & $\begin{array}{c}\text { LOD }^{a} \\
(\mu \mathrm{g} / \mathrm{g} \mathrm{ww}, \text { mean })\end{array}$ & $\begin{array}{l}\mathrm{PQL}^{\mathrm{b}}(\mathrm{ppm}, \\
\text { mean) }\end{array}$ & $\begin{array}{l}\text { Calibration Blank } \\
\text { (ppm, mean) } \\
n=5\end{array}$ & $\begin{array}{c}\text { Duplicate (RPD) } \\
(\%) \\
n=1\end{array}$ & $\begin{array}{l}\text { LCS recovery (\%) } \\
\qquad n=1\end{array}$ & $\begin{array}{l}\text { Spike recovery }(\%) \\
\qquad n=1\end{array}$ & $\begin{array}{c}\text { SRM }^{d} \text { recovery (\%) DORM-3/ } \\
\text { DOLT-4 } \\
n=1\end{array}$ \\
\hline $\mathrm{Ag}$ & 0.08 & 0.80 & $\mathrm{BDL}^{\mathrm{e}}$ & 10.7 & 95.3 & 87.2 & 103.2 \\
\hline
\end{tabular}

aLOD=Limit of detection

${ }^{\mathrm{P}} \mathrm{PQL}=$ Project quantitation limit

${ }^{\mathrm{C}} \mathrm{RPD}=$ Relative percent difference

dSRM $=$ Standard reference material

${ }^{\mathrm{e} B D L}=$ Below detection limit 
Citation: Savery LC, Wise SS, Falank C, Wise J, Gianios C Jr (2013) Global Assessment of Silver Pollution using Sperm Whales (Physeter macrocephalus) as an Indicator Species. J Environ Anal Toxicol 3: 169. doi:10.4172/2161-0525.1000169

Page 4 of 8

Table 2: Global distribution of sperm whale skin Ag concentrations.

\begin{tabular}{|c|c|c|c|c|c|}
\hline Ocean/Sea & Region $^{a}$ & $\mathrm{n}$ & $\#$ of $\mathrm{ND}^{\mathrm{c}}$ & Regional Mean ${ }^{b}$ & Ocean/Sea Mean ${ }^{b}$ \\
\hline \multirow{6}{*}{ Pacific } & Sea of Cortez & 25 & 6 & $1.4 \pm 0.4(0.2-6.5)$ & \multirow{6}{*}{4.2} \\
\hline & Galapagos & 7 & 3 & $2.2 \pm 1.5(0.1-10.7)$ & \\
\hline & Pacific & 22 & 5 & $2.0 \pm 0.9(0.1-15.7)$ & \\
\hline & Kiribati & 1 & 0 & 4.2 & \\
\hline & Papua New Guinea & 23 & 4 & $10.3 \pm 5.1(0.2-94.4)$ & \\
\hline & Australia & 16 & 8 & $4.8 \pm 4.3(0.1-68.7)$ & \\
\hline \multirow{7}{*}{ Indian } & Cocos & 18 & 6 & $0.2 \pm 0.1(0.04-1.3)$ & \multirow{7}{*}{23.1} \\
\hline & Indian & 4 & 4 & ND & \\
\hline & Chagos & 12 & 6 & $0.1 \pm 0.1(0.1-0.7)$ & \\
\hline & Seychelles & 34 & 12 & $123.3 \pm 122.9(0.1-4179.0)$ & \\
\hline & Maldives & 35 & 24 & $0.3 \pm 0.1(0.3-2.1)$ & \\
\hline & Sri Lanka & 24 & 20 & $12.5 \pm 12.4(0.1-297.3)$ & \\
\hline & Mauritius & 29 & 13 & $1.9 \pm 1.7(0.1-49.7)$ & \\
\hline Mediterranean & Mediterranean & 23 & 4 & $1.5 \pm 0.5(0.2-9.5)$ & 1.5 \\
\hline \multirow{2}{*}{ Atlantic } & Canaries & 23 & 5 & $0.5 \pm 0.1(0.1-1.5)$ & \multirow{2}{*}{5.9} \\
\hline & Bahamas & 2 & 0 & $11.2 \pm 10.5(0.6-21.7)$ & \\
\hline Global & & 298 & 120 & $16.9 \pm 14.1(0.04-4179.0)$ & \\
\hline
\end{tabular}

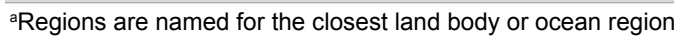

${ }^{b}$ All data are presented in $\mu \mathrm{g} / \mathrm{g} w w \pm$ standard error

cWhales with nondetectable Ag levels had one-half LOD $(0.04 \mu \mathrm{g} / \mathrm{g} \mathrm{ww})$ used in analysis

$\mathrm{n}$ : Sample size

( ) Minimum and maximum values.

ND: Nondetect

Table 3: Sperm whale skin Ag concentration by gender across regions.

\begin{tabular}{|c|c|c|c|c|c|}
\hline \multirow{2}{*}{ Ocean/Sea } & \multirow{2}{*}{ Region ${ }^{a}$} & \multicolumn{2}{|c|}{$\mathrm{n}$} & \multicolumn{2}{|c|}{$\mathrm{Ag}^{\mathrm{b}}$} \\
\hline & & M & $\mathrm{F}$ & M & $\mathrm{F}$ \\
\hline \multirow{6}{*}{ Pacific } & Sea of Cortez & $12^{c}$ & $13^{c}$ & $1.1 \pm 0.4(0.2-1.7)$ & $1.8 \pm 0.6(0.2-6.5)$ \\
\hline & Galapagos & $7^{c}$ & 0 & $2.2 \pm 1.5(0.1-10.7)$ & - \\
\hline & Pacific & $6^{c}$ & $16^{c}$ & $2.9 \pm 2.6(0.1-15.7)$ & $1.6 \pm 0.8(0.1-13.0)$ \\
\hline & Kiribati & 0 & 1 & - & 4.2 \\
\hline & Papua New Guinea & $10^{c}$ & $13^{c}$ & $11.1 \pm 7.5(0.2-75.6)$ & $9.8 \pm 7.1(0.4-94.4)$ \\
\hline & Australia & $8^{c}$ & $8^{c}$ & $0.4 \pm 0.2(0.1-1.3)$ & $9.2 \pm 8.5(4.3-68.7)$ \\
\hline \multirow{7}{*}{ Indian } & Cocos & 0 & $18^{\mathrm{c}}$ & - & $0.2 \pm 0.1(0.04-1.3)$ \\
\hline & Indian & $4^{c}$ & 0 & ND & - \\
\hline & Chagos & $12^{c}$ & 0 & $0.1 \pm 0.1(0.1-0.7)$ & - \\
\hline & Seychelles & $9^{c}$ & $25^{c}$ & $464.9 \pm 464.3(0.1-4,179.0)$ & $0.3 \pm 0.1(0.1-1.8)$ \\
\hline & Maldives & $9^{c}$ & $26^{c}$ & $0.4 \pm 0.2(0.3-2.1)$ & $0.2 \pm 0.05(0.3-1.0)$ \\
\hline & Sri Lanka & $1^{c}$ & $23^{c}$ & ND & $13.0 \pm 12.9(0.1-297.3)$ \\
\hline & Mauritius & 3 & $26^{c}$ & $0.1 \pm 0.01 \quad(0.06-0.08)$ & $2.1 \pm 1.9(0.1-49.7)$ \\
\hline Mediterranean & Mediterranean & $16^{c}$ & 7 & $1.0 \pm 0.6(0.2-9.5)$ & $2.6 \pm 1.0(0.4-6.1)$ \\
\hline \multirow{2}{*}{ Atlantic } & Canaries & 6 & $17^{c}$ & $0.7 \pm 0.2(0.1-1.4)$ & $0.5 \pm 0.1(0.1-1.5)$ \\
\hline & Bahamas & 1 & 1 & 0.6 & 21.7 \\
\hline Total & Global & 104 & 194 & $42.0 \pm 40.2(0.1-4179.0)$ & $3.5 \pm 1.7(0.04-297.3)$ \\
\hline
\end{tabular}

M: Male; F: Female

$\mathrm{n}$ : Sample size

- None sampled

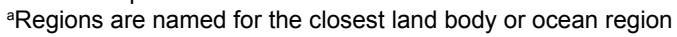

${ }^{\mathrm{b}}$ All data are mean total $\mathrm{Ag}$ concentration presented in $\mu \mathrm{g} / \mathrm{g}$ ww \pm standard error with minimum and maximum values in ()

'One or more whale had undetectable Ag concentrations. One-half the detection concentration $(0.01 \mu \mathrm{g} / \mathrm{g}$ ww) was used in the analysis 
Citation: Savery LC, Wise SS, Falank C, Wise J, Gianios C Jr (2013) Global Assessment of Silver Pollution using Sperm Whales (Physeter macrocephalus) as an Indicator Species. J Environ Anal Toxicol 3: 169. doi:10.4172/2161-0525.1000169

for region, Ag levels in males and females were statistically different from one another $(\mathrm{F}(16,280)=5.06 ; \mathrm{p}=<0.0001)$ as well as Ag levels in adult males being statistically different than females $(\mathrm{F}(15,228)=5.41$; $\mathrm{p}=<0.0001)$

Considering gender by region, the region with the highest $\mathrm{Ag}$ concentration for females was in the waters near the Bahamas $(\mathrm{n}=1)$ with $21.7 \mu \mathrm{g} / \mathrm{g}$ ww and in Sri Lanka ( $\mathrm{n}=23)$ with $13.0 \pm 12.9 \mu \mathrm{g} / \mathrm{g}$ ww ranging from 0.1 to $297.3 \mu \mathrm{g} / \mathrm{g}$ ww. The lowest regional mean concentration for females was near the Cocos Islands $(\mathrm{n}=18)$ with 0.2 $\pm 0.1 \mu \mathrm{g} / \mathrm{g}$ ww ranging from 0.04 to $1.3 \mu \mathrm{g} / \mathrm{g} w \mathrm{w}$ and in the Maldives ( $\mathrm{n}=26)$ with $0.2 \pm 0.05 \mu \mathrm{g} / \mathrm{g}$ ww ranging from 0.3 to $1.0 \mu \mathrm{g} / \mathrm{g} w \mathrm{w}$. The variation among regions was statistically significant $(\mathrm{F}(11,180)=5.91$; $\mathrm{p}<0.001)$. Pair-wise $\mathrm{t}$-tests comparing females by region found significant differences $(\mathrm{p}<0.05)$ in Ag levels of females between the regions of the Cocos compared to the Mediterranean, Papua New Guinea, and Sea of Cortez; Maldives to the Mediterranean, Papua New Guinea, and Sea of Cortez; Mauritius to Mediterranean, Papua New Guinea, and Sea of Cortez; Mediterranean to Seychelles and Sri Lanka; Papua New Guinea to Seychelles and Sri Lanka; and Sea of Cortez to Seychelles and Sri Lanka.

The highest regional mean Ag concentration in males was in Seychelles $(\mathrm{n}=9)$ with a mean of $464.9 \pm 464.3 \mu \mathrm{g} / \mathrm{g}$ ww ranging from 0.1 to $4,179 \mu \mathrm{g} / \mathrm{g}$ ww and in Papua New Guinea $(\mathrm{n}=10)$ with $11.1 \pm$ $7.5 \mu \mathrm{g} / \mathrm{g}$ ww ranging from 0.2 to $75.6 \mu \mathrm{g} / \mathrm{g}$ ww. If the male sample from Seychelles with the high Ag concentration is removed from the analysis, then Papua New Guinea is the region with the highest mean Ag concentration for the males sampled. The lowest regional mean $\mathrm{Ag}$ concentration in males was in the Indian Ocean with all four samples having undetectable levels (one-half $\mathrm{LOD}=0.04 \mu \mathrm{g} / \mathrm{g} \mathrm{ww}$ ). There were statistical differences among males between regions $(F(13,90)=2.00$; $\mathrm{p}=0.03$ ) whether the high sample in Seychelles is removed or not $(F(13,89)=2.35 ; \mathrm{p}=0.01)$. Papua New Guinea was significantly different than Chagos and the Indian Ocean Crossing.

\section{Silver concentration comparisons by age in males}

We found no conclusive evidence that older and subsequently larger males had higher Ag burdens (Table 4). Adult males $(\mathrm{n}=51)$ had a mean $\mathrm{Ag}$ concentration of $1.5 \pm 0.6 \mu \mathrm{g} / \mathrm{g}$ ww ranging from 0.1 to $23.6 \mu \mathrm{g} / \mathrm{g}$ ww compared to subadult males $(\mathrm{n}=53)$ with $81.0 \pm 78.8$ $\mu \mathrm{g} / \mathrm{g}$ ww ranging from 0.1 to $4179 \mu \mathrm{g} / \mathrm{g} w \mathrm{w}$, and this difference was not statistically significant $(F(1,102)=0.01 ; p=0.93)$. When the subadult male in Seychelles with the high concentration of Ag was removed from the analysis, the mean $\mathrm{Ag}$ concentration for subadult males $(\mathrm{n}=52)$ is $2.2 \pm 1.5 \mu \mathrm{g} / \mathrm{g}$ ww ranging from 0.1 to $75.6 \mu \mathrm{g} / \mathrm{g}$ ww and again the $\mathrm{Ag}$ concentrations in subadult male whales were not statistically different than adult male whales $(\mathrm{F}(1,101)=0.40 ; \mathrm{p}=0.53)$.

There was no statistically significant variation across regions in adult $(\mathrm{F}(10,40)=1.23 ; \mathrm{p}=0.30)$ or subadult males $(\mathrm{F}(9,43)=1.87 ; \mathrm{p}=0.08)$. The highest regional mean $\mathrm{Ag}$ concentration for adult male was in the Papua New Guinea with $5.0 \pm 4.7 \mu \mathrm{g} / \mathrm{g}$ ww ranging from 0.2 to 23.6 $\mu \mathrm{g} / \mathrm{g} w w$ and then in Mauritius with $0.07 \pm 0.01 \mu \mathrm{g} / \mathrm{g}$ ww ranging from $0.06-0.07 \mu \mathrm{g} / \mathrm{g}$ ww. The highest regional mean for subadults was in the Seychelles with $1,045 \pm 1,045 \mu \mathrm{g} / \mathrm{g}$ ww ranging from 0.4 to $4179 \mu \mathrm{g} / \mathrm{g}$ ww, and the lowest in Chagos with $0.1 \pm 0.7 \mu \mathrm{g} / \mathrm{g}$ ww ranging from 0.1 to $0.7 \mu \mathrm{g} / \mathrm{g}$ ww. If the subadult male from Seychelles with the high Ag concentration is removed from the analysis, there is a significant difference across regions for subadult males $(F(9,42)=2.31 ; p=0.03)$

Table 4: Sperm whale skin Ag concentration by age in males across regions.

\begin{tabular}{|c|c|c|c|c|c|}
\hline \multirow{2}{*}{ Ocean/Sea } & \multirow{2}{*}{ Regiona } & \multicolumn{2}{|c|}{$\mathrm{n}$} & \multicolumn{2}{|l|}{$\mathrm{Ag}^{\mathrm{b}}$} \\
\hline & & SM & A & SM & A \\
\hline \multirow{6}{*}{ Pacific } & Sea of Cortez & 0 & $12^{\mathrm{c}}$ & - & $1.1 \pm 0.4(0.2-1.7)$ \\
\hline & Galapagos & $5^{c}$ & $2^{c}$ & $2.8 \pm 2.0(0.1-10.7)$ & ND \\
\hline & Pacific & 0 & $6^{c}$ & - & $0.2 \pm 23.6(0.3-2.4)$ \\
\hline & Kiribati & 0 & 0 & - & - \\
\hline & Papua New Guinea & $5^{c}$ & 5 & $17.2 \pm 14.6(1.9-75.6)$ & $5.0 \pm 4.7(0.2-23.6)$ \\
\hline & Australia & $8^{c}$ & 0 & $0.4 \pm 0.2(0.1-1.3)$ & - \\
\hline \multirow{7}{*}{ Indian } & Cocos & 0 & 0 & - & - \\
\hline & Indian & 0 & $4^{c}$ & - & ND \\
\hline & Chagos & $12^{\mathrm{c}}$ & 0 & $0.1 \pm 0.7(0.1-0.7)$ & - \\
\hline & Seychelles & $4^{c}$ & $5^{c}$ & $1,045.0 \pm 1,045.0(0.4-4179.0)$ & $0.9 \pm 0.4(0.1-2.4)$ \\
\hline & Maldives & $5^{c}$ & $4^{c}$ & $0.2 \pm 0.1(0.26-0.32)$ & $0.8 \pm 0.5(0.9-2.1)$ \\
\hline & Sri Lanka & 0 & $1^{c}$ & - & 0.1 \\
\hline & Mauritius & 1 & 2 & 0.08 & $0.07 \pm 0.01(0.06-0.07)$ \\
\hline Mediterranean & Mediterranean & $8^{c}$ & $8^{c}$ & $0.5 \pm 0.2(0.4-1.4)$ & $1.5 \pm 1.1(0.2-9.5)$ \\
\hline \multirow{2}{*}{ Atlantic } & Canaries & 4 & 2 & $0.7 \pm 0.3(0.1-1.4)$ & $0.6 \pm 0.5(0.1-1.1)$ \\
\hline & Bahamas & 1 & 0 & 0.6 & - \\
\hline Total & Global & 53 & 51 & $81.0 \pm 78.8(0.1-4179.0)$ & $1.5 \pm 0.6(0.1-23.6)$ \\
\hline
\end{tabular}

A: Adult male; SM: Subadult male

$\mathrm{n}$ : Sample size

- None sampled

aRegions are named for the closest land body or ocean region

${ }^{b}$ All data are mean total $\mathrm{Ag}$ concentration presented in $\mu \mathrm{g} / \mathrm{g} \mathrm{ww} \pm$ standard error with minimum and maximum values in ( )

'This region had whales with nondetectable Ag concentrations. One-half the detection concentration $(0.04 \mu \mathrm{g} / \mathrm{g}$ ww) was used in the analysis 
with the highest levels in Papua New Guinea (n=5) with $17.2 \pm 14.6$ $\mu \mathrm{g} / \mathrm{g}$ ww ranging from 1.9 to $75.6 \mu \mathrm{g} / \mathrm{g} w \mathrm{w}$.

\section{Silver levels in sloughed skin}

Ag levels were measured in two sloughed skin samples found in Seychelles that were from males (data not shown). The Ag levels of the two samples were 0.6 and $21.7 \mu \mathrm{g} / \mathrm{g}$ ww. In comparison to the skin biopsy samples of males from Seychelles that had a mean Ag concentration of $464.9 \pm 464.3 \mu \mathrm{g} / \mathrm{g}$ ww ranging from 0.1 to $4179 \mu \mathrm{g} / \mathrm{g}$ ww, the sloughed skin levels were lower than the skin biopsy mean; however, still within the minimum and maximum Ag levels found. If the high sample found in Seychelles is removed, then the mean $\mathrm{Ag}$ concentration for this region for males is $0.7 \pm 0.3 \mu \mathrm{g} / \mathrm{g} w w$, which would put one of the sloughed skin samples on the higher end of the range found in the biopsies. Taken together, $\mathrm{Ag}$ can be eliminated from the skin by epidermal sloughing.

\section{Discussion}

\section{Global distribution of $\mathrm{Ag}$}

To our knowledge, this is the first global study of the distribution of Ag, a contaminant of concern due to its toxicity and ability to bioaccumulate in the marine environment. We found detectable Ag levels in every region we tested except the Indian Ocean crossing where the four biopsies had undetectable levels. The wide distribution of $\mathrm{Ag}$ may be explained by the fact that once this metal enters marine waters it binds strongly to chloro complexes causing Ag to be highly bioavailable and remain in solution enabling wide dispersal [1] with a residence time $<1$ year [24].

One example of its wide dispersal is from wastewater fallouts off of Los Angeles and San Diego where the Ag gradient extends over 250 $\mathrm{km}$ [25]. Ag is shown to be bioavailable in marine sediments where it undergoes high bioaccumulation [1]; however, Ag is predominantly bound to sulfur in sediment, which is a less toxic form of $\mathrm{Ag}$ [26]. Sperm whales feed at deep ocean depths (up to $5000 \mathrm{~m}$ ) including the ocean floor on squid, fish, rays and sharks [27] that may bioaccumulate Ag levels from these marine sediments.

\section{Silver levels in cetacean skin}

Our data are the first to report Ag levels in sperm whales. We sampled free-ranging sperm whales limiting the option of available tissue to skin and blubber. Metals accumulate at higher levels in the skin, so we focused on skin levels. Only one other study considers Ag levels in cetacean skin and reports $0.003 \mu \mathrm{g} / \mathrm{g}$ ww in a Dall's porpoise found on the Sanriku coast of Japan [28]. This concentration is consistent with the low end of our range; however, it is only one animal.

Our limited data in sloughed skin from Seychelles show $\mathrm{Ag}$ concentrations within the range of levels found in the skin biopsies showing that epidermal sloughing can be a route for elimination of $\mathrm{Ag}$, although likely a minor one.

\section{Possible routes of exposure to silver for the sperm whale}

The source of Ag exposure for the sperm whales sampled cannot be determined from a skin biopsy; however, may occur through ingestion, inhalation and skin absorption. Ingestion of $\mathrm{Ag}$ occurs through consumption of contaminated prey since Ag bioaccumulates in marine organisms and also through swallowing seawater. Dolphins have been reported to swallow about $1.5 \mathrm{l}$ /day [29], but the amount is unknown in sperm whales. Once ingested the exact mechanism of $\mathrm{Ag}$ uptake into a cell is unclear; however, it is believed to enter through active transport [2].

Inhalation is another possible route of Ag exposure to sperm whales because whales inhale large volumes of air and hold their breath for long periods of time allowing for more absorption. But, inhalation is rarely considered in the marine environment. Recently, we calculated a theoretical amount of chromium (Cr) inhalation in whales based on marine air levels. Although these air $\mathrm{Cr}$ levels were low, the calculation shows that the whales would likely inhale an amount of $\mathrm{Cr}$ equivalent to occupational exposure workers [22]. Overall, the majority of $\mathrm{Ag}$ emissions into the environment binds to sediments or suspended particles near the release site and becomes immobile; however, a portion is transported long distances through air [2]. In general, atmospheric Ag concentrations have been found to be $<1 \mathrm{ng} / \mathrm{m}^{3}$ [5], but could be much higher if near a silver-based industry.

Ag could also possibly enter the sperm whale through skin absorption; however, this is unlikely due to the fact that $\mathrm{Ag}$ has not been shown to enter a cell by passive diffusion [2].

\section{Regional differences of silver levels in toothed whales}

Between regions, $\mathrm{Ag}$ concentrations in our data set varied with levels being the highest in the Indian $>$ Atlantic $>$ Pacific $>$ Mediterranean. The Pacific waters have been found to have higher Ag concentrations than the Atlantic [9], and it is unknown why the Ag concentrations in these skin biopsies did not reflect the seawater concentrations found in other studies.

Our data are the first to report Ag levels in whales from the Indian Ocean and Mediterranean Sea. Marine pollution is poorly understood in the Indian Ocean, despite the importance of this body of water. This report builds on our previous study of Cr levels, which were generally high in whales from these regions [22], and extends our knowledge to include Ag. More work is needed to understand pollution in the Indian Ocean.

In 1999, the Indian Ocean Experiment was conducted and found surprising high levels of air pollution over the Indian Ocean and was suggested to originate from fossil fuel combustion and biomass burning from south and Southeast Asia and India [30]. Ag emissions into the Indian Ocean from river input was discovered from the coast of Kenya where Ag sediment concentrations were found ranging from 1.3 to 18.5 $\mu \mathrm{g} / \mathrm{g} \mathrm{dw}[31]$. These two studies along with this study are revealing the impact of pollution and specifically Ag pollution to the Indian Ocean.

Our average concentration for the Atlantic Ocean was $5.9 \mu \mathrm{g} / \mathrm{g}$ ww. $\mathrm{Ag}$ concentrations in deep seawater from the Atlantic have been found ranging from 7 to $23 \mathrm{pM}$ [9], which in comparison to our mean $\mathrm{Ag}$ concentration of $54.7 \mu \mathrm{M}$ depicts the ability of $\mathrm{Ag}$ bioaccumulation in an oceanic species.

Our mean Ag concentration for the Atlantic was on the high end of other Ag concentration reported in this region and included samples from the Canaries $(0.5 \mu \mathrm{g} / \mathrm{g} \mathrm{ww})$ and the Bahamas $(11.2 \mu \mathrm{g} / \mathrm{g}$ $\mathrm{ww})$. Pilot whales (Globicephala melas) from Cape $\operatorname{Cod}(\mathrm{n}=8)$ have liver Ag concentrations of $0.2 \mu \mathrm{g} / \mathrm{g}$ ww [18]. Law et al. [19] consider Ag concentration in liver tissue from several species of cetaceans including long-finned pilot whale (Globicephala melas), Sowerby's beaked whale (Mesoplodon bidens), fin whale (Balaenoptera phsalus), minke whale (Balaenoptera), pygmy sperm whale (Kogia breviceps) and Blainville's beaked whale (Mesoplodon densirostris) that stranded off the east coast of England and Wales. The individual levels range from 0.05-5.5 $\mu \mathrm{g} / \mathrm{g}$ ww though the number of animals are small (one per species) [19]. 
In the Pacific Ocean, the mean $\mathrm{Ag}$ concentration was $4.2 \mu \mathrm{g} / \mathrm{g}$ ww. As concentrations in seawater from the deep waters of the Pacific range from 22 to $80 \mathrm{pM}[10,24,32]$ in comparison to our mean Ag concentration of $38.9 \mu \mathrm{M}$ again showing the ability of Ag to bioaccumulate in sperm whales.

Our mean Pacific Ag concentration was well above the range reported in other studies from this area. Ag levels in the liver and kidney from several species of toothed whales including the bottlenose dolphin (Tursiops truncatus), common dolphin (Delphinus delphis) and melon-headed whale (Peponocephala electra) that had stranded off the east coast of Australia were all less than $1.0 \mu \mathrm{g} / \mathrm{g}$ ww though the number of animals were small (three or less per species) [21].

\section{Hotspots of silver levels in the oceanic environment}

Our data and the published literature are consistent with the hypothesis that there are hotspots of Ag exposure concentrating to a moderate extent in marine mammals [5]. We found that Ag levels in sperm whale skin are generally low, but there are a few hotspots that had skin samples with Ag levels greater than $10 \mu \mathrm{g} / \mathrm{g}$ ww in the Pacific crossing, Australia, Mauritius, Seychelles, Sri Lanka and Papua New Guinea. Additionally, a whale in the waters near Seychelles had the highest Ag concentration sampled of $4,179 \mu \mathrm{g} / \mathrm{g}$ ww.

The Pacific is an interesting case as our data may suggest that there is an increase in $\mathrm{Ag}$ levels or perhaps there are regional hotspots within it. Previous marine Ag studies largely focus on opportunistically obtained samples in a few well-researched areas of the Northern hemisphere. Thus, it is unclear if Ag levels observed reflected regional problems or something of a more global concern.

\section{Silver levels compared by gender}

Data in beluga whales from Alaska show that females had higher (33.1 $\mu \mathrm{g} / \mathrm{g}$ ww; $\mathrm{n}=6) \mathrm{Ag}$ concentrations than males $(21.2 \mu \mathrm{g} / \mathrm{g}$ ww; $\mathrm{n}=9$ ); however, it is unknown if this difference is significant or not [18]. We did not find that females sperm whales had statistically significant higher Ag levels compared to males.

\section{Silver levels by age}

Becker et al. [18] reports that Ag levels in the liver of pilot and beluga whales appear to increase with age but not with length. Klaine et al. [33], finds in freshwater fish that silver nitrate toxicity is higher in 28 day old fish compared to 3 day old fish. However, we did not find that our subadult males differed in Ag concentrations compared to adults. This may be a consequence of not being able to determine a more exact age of the whales or may be due to the small sample size per region and the considerable range of $\mathrm{Ag}$ concentrations in many of the regions that may have obscured possible age-related differences.

\section{Skin Ag levels in relation to levels in other organs}

Ag is known to bioaccumulate in marine mammals [2]. Studies in rats and mice report $\mathrm{Ag}$ first accumulates in the liver and then kidney, spleen, skin, bones and muscle [2]. Klaassen [34] also shows that in rats, rabbits and dogs that ${ }^{110} \mathrm{Ag}$ administered intravenously accumulates to highest concentrations in the liver $2 \mathrm{~h}$ after treatment. Therefore, it is probable that the Ag concentrations in the liver of our sampled sperm whales were higher than what was measured in the skin.

Other studies considering Ag in whale species were from stranded or subsistence-hunted animals so internal organs were available, particularly liver. In subsistence-hunted gray whales (Eschrichtus robustus) ( $\mathrm{n}=6-14)$ from the Arctic, mean Ag concentrations were 1,11 and $310 \mu \mathrm{g} / \mathrm{g} w \mathrm{w}$ for kidney, brain and liver, respectively [20]. Mean Ag levels in the liver of subsistence-hunted beluga whales from Alaska (Delphinapterus leucas) are $19.3 \mu \mathrm{g} / \mathrm{g}$ ww in Point Hope $(\mathrm{n}=4)$ and $31.0 \mu \mathrm{g} / \mathrm{g} w w$ in Point Lay $(\mathrm{n}=10)$ [18]. Thus, our global mean Ag concentration $(16.9 \mu \mathrm{g} / \mathrm{g} \mathrm{ww})$ in skin of sperm whales lies at the low end of the average Ag levels found in livers of toothed whales in the

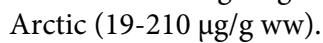

\section{Possible effects of elevated Ag levels}

The hotspots of elevated Ag levels in our data set may render marine organisms more sensitive to the toxicity of other chemicals and to diseases especially those known to induce lipid peroxidation themselves [35]. There is evidence that $\mathrm{Ag}$ is a potent inhibitor of selenium, an essential element that functions as an antioxidant for the cell particularly being an integral part of glutathione peroxidase [36]. Ag has also been shown to be a potent inhibitor of glutathione peroxidase [37,38] and to induce lipid peroxidation [18]. The effect of the higher $\mathrm{Ag}$ concentrations found in the skin of these whales is unknown; however, this organ may act as a reservoir for $\mathrm{Ag}$ where it is slowly removed by eternal sloughing.

\section{Conclusions}

The data shown here represent a global baseline for marine Ag, which was established using the skin of sperm whales as an indicator species. These data indicate that sperm whales are indeed exposed to Ag, but Ag concentrations were generally low in these animals prior to 2005 , thus providing an important and useful baseline to eventually determine if AgNPs are impacting the marine environment. These data suggest that $\mathrm{Ag}$ concentrations may be increasing in the Pacific though more work is needed to assess whether these observations reflect a general trend in the Pacific or it is due to more localized regional events. Additional work is needed to understand the toxicity of Ag to whales and how it transports through the environment to reach remote regions.

\section{Acknowledgments and Grants}

We are grateful to the crew of the Odyssey who were involved in collecting samples and to the staff at Ocean Alliance who managed this global expedition. We appreciate the technical assistance provided by Drs. Gregory Buzard, Hong Xie and Lucille Benedict. We express thanks to the many financial supporters of Ocean Alliance and the Maine Center for Toxicology and Environmental Health. This research conforms to the legal requirements of the country in which it was carried out including those relating to conservation and animal welfare. Work was conducted under NMFS permit \#1008-1637-00 (John P. Wise, Sr., PI) and permit \#751-1614 (lain Kerr, PI).

\section{References}

1. Luoma SN, Ho YB, Bryan GW (1995) Fate, bioavailability and toxicity of silver in estuarine environments. Mar Pollut Bull 31: 44-54.

2. Ratte HT (1999) Bioaccumulation and toxicity of silver compounds: A review Environ Toxicol Chem 18: 89-108.

3. Lam IK, Wang WX (2006) Accumulation and elimination of aqueous and dietary silver in Daphnia magna. Chemosphere 64: 26-35.

4. Bianchini A, Playle RC, Wood CM, Walsh PJ (2005) Mechanism of acute silver toxicity in marine invertebrates. Aquat Toxicol $72: 67-82$

5. ATSDR (1990) Toxicological Profile for Silver. US Department of Health and Human Services, Public Health Service, Agency for Toxic Substances and Disease Registry (ATSDR), Atlanta, Georgia, USA

6. Webb NA, Wood CM (2000) Bioaccumulation and distribution of silver in fou marine teleosts and two marine elasmobranchs: influence of exposure duration, concentration, and salinity. Aquat Toxicol 49: 111-129. 
Citation: Savery LC, Wise SS, Falank C, Wise J, Gianios C Jr (2013) Global Assessment of Silver Pollution using Sperm Whales (Physeter macrocephalus) as an Indicator Species. J Environ Anal Toxicol 3: 169. doi:10.4172/2161-0525.1000169

Page 8 of 8

7. US Environmental Protection Agency (2002) National Recommended Water Quality Criteria: 2002. EPA-822-R-02-047. Washington D.C, USA

8. Engel DW, Sunda WG, Fowler BA (1981) Factors affecting trace metal uptake and toxicity to estuarine organisms. I. Environmental parameters. In: Biological monitoring of marine pollutants. Vernberg FJ, Calabrese A, Thurberg FP, Vernberg WB Academic Press, New York, USA.

9. Rivera-Duarte I, Flegal AR, Sanudo-Wilhelmy SA, Veron AJ (1999) Silver in the far North Atlantic Ocean. Deep Sea Research Part II: Topical Studies in Oceanography 46: 979-990.

10. Kramer D, Cullen JT, Christian JR, Johnson WK, Pedersen TF (2011) Silver in the subarctic northeast Pacific Ocean: Explaining the basin scale distribution of silver. Mar Chem 123: 133-142.

11. Flegal A, Sanudo-Wilhelmy SA, Scelfo GM (1995) Silver in the eastern Atlantic Ocean. Mar Chem 49: 315-320.

12. Baker C, Pradhan A, Pakstis L, Pochan DJ, Shah SI (2005) Synthesis and antibacterial properties of silver nanoparticles. J Nanosci Nanotechnol 5: 244249.

13. Tang SC, Tang Y, Gao F, Liu Z, Meng X (2007) Ultrasonic electrodeposition of silver nanoparticles on dielectric silica spheres. J Nanotechnol 18: 295607-12.

14. Kim S, Choi JE, Choi J, Chung KH, Park K, et al. (2009) Oxidative stressdependent toxicity of silver nanoparticles in human hepatoma cells. Toxicol In Vitro 23: 1076-1084.

15. Colman BP, Wang SY, Auffan M, Wiesner MR, Bernhardt ES (2012) Antimicrobial effects of commercial silver nanoparticles are attenuated in natural streamwater and sediment. Ecotoxicology 21: 1867-77.

16. Yin L, Cheng Y, Espinasse B, Colman BP, Auffan M, et al. (2011) More than the ions: the effects of silver nanoparticles on Lolium multiflorum. Environ Sci Technol 45: 2360-2367.

17. Corley EA, Scheufele DA, Hu Q (2009) Of risks and regulations: how leading U.S. nanoscientists form policy stances about nanotechnology. J Nanopart Res 11: 1573-1585.

18. Becker PR, Mackey EA, Demiralp R, Suydam R, Early G, et al. (1995) Relationship of silver with selenium and mercury in the liver of two species of toothed whales (odontocetes). Mar Pollut Bull 30: 262-271.

19. Law RJ, Bennett ME, Blake SJ, Allchin CR, Jones BR, et al. (2001) Metals and organochlorines in pelagic cetaceans stranded on the coasts of England and Wales. Mar Pollut Bull 42: 522-526.

20. Tilbury KL, Stein JE, Krone CA, Brownell RL Jr, Blokhin SA, et al. (2002) Chemical contaminants in juvenile gray whales (Eschrichtius robustus) from a subsistence harvest in Arctic feeding grounds. Chemosphere. 47: 555-564.

21. Law RJ, Morris RJ, Allchin CR, Jones BR, Nicholson MD (2003) Metals and organochlorines in small cetaceans stranded on the east coast of Australia. Mar Pollut Bull 46: 1206-1211.

22. Wise JP Sr, Payne R, Wise SS, LaCerte C, Wise J, et al. (2009) A global assessment of chromium pollution using sperm whales (Physeter macrocephalus) as an indicator species. Chemosphere 75: 1461-1467.

23. Brown MW, Kraus SD, Gaskin DE (1991) Reaction of North Atlantic right whales (Eubalaena glacialis) to skin biopsy sampling for genetic and pollutant analysis. Reports of the International Whaling Commission 13: 81-90.

24. Martin JH, Knauer GA, Gordon RM (1983) Silver distributions and fluxes in north-east Pacific waters. Nature 305: 306-309.

25. Sanudo-Wilhelmy SA, Flegal AR (1992) Anthropogenic Silver in the Southern California Bight: A New Tracer of Sewage in Coastal Waters. Environ Sci Technol 26: 2147-2151.

26. McKay JL, Pedersen TF (2008) The accumulation of silver in marine sediments: A link to biogenic Ba and marine productivity. Global Biogeochem Cycles 22.

27. Whitehead H (2003) Sperm Whales: Social Evolution in the Ocean. (1stedn), The University of Chicago Press Chicago, USA.

28. Yang J, Miyazaki N, Kunito T, Tanabe S (2006) Trace elements and butyltins in a Dall's porpoise (Phocoenoides dalli) from the Sanriku coast of Japan. Chemosphere 63: 449-457.

29. Augier H, Benkoel L, Chamlian A, Park WK, Ronneau C (1993) Mercury, zinc and selenium bioaccumulation in tissues and organs of Mediterranean striped dolphins Stenella coeruleoalba meyen. Toxicological result of their interaction. Cell Mol Biol (Noisy-le-grand) 39: 621-634.

30. Lelieveld J, Crutzen PJ, Ramanathan V, Andreae MO, Brenninkmeijer CM, et al. (2001) The Indian Ocean Experiment: Widespread Air Pollution from South and Southeast Asia. Science 291: 1031-1036.

31. Ochieng EZ, Lalah JO, Wandiga SO (2009) Anthropogenic sources of heavy metals in the Indian Ocean coast of Kenya. Bull Environ Contam Toxicol 83. 600-607.

32. Murozumi M (1981) Isotope dilution surface ionization mass spectrometry of trace constituents in natural environments and in the Pacific. Anal Sci 30: 19 36 .

33. Klaine SJ, Bills TL, Wenholz MD, La Point TW, Cobb GP, et al. (1996) Influence of age sensitivity on the acute toxicity of silver to fathead minnows at various water quality parameters. Proceedings, 4th Argentum International Conference on the Transport, Fate, and Effects of Silver in the Environment, Madison, WI, USA.

34. Klaassen CD (1979) Biliary excretion of silver in the rat, rabbit, and dog. Toxico Appl Pharmacol 50: 49-55.

35. Rungby J (1987) Silver-induced lipid peroxidation in mice: interactions with selenium and nickel. Toxicology 45: 135-142.

36. Burk RF (2002) Selenium, an Antioxidant Nutrient. Nutr Clin Care 5: 75-79.

37. Ridlington JW, Whanger PD (1981) Interactions of selenium and antioxidants with mercury, cadmium and silver. Fundam Appl Toxicol 1: 368-375.

38. Sugawara N, Sugawara C (1984) Comparative study of effect of acute administration of cadmium and silver on ceruloplasmin and metallothionein involvement of disposition of copper, iron, and zinc. Environ Res 35: 507-515. 